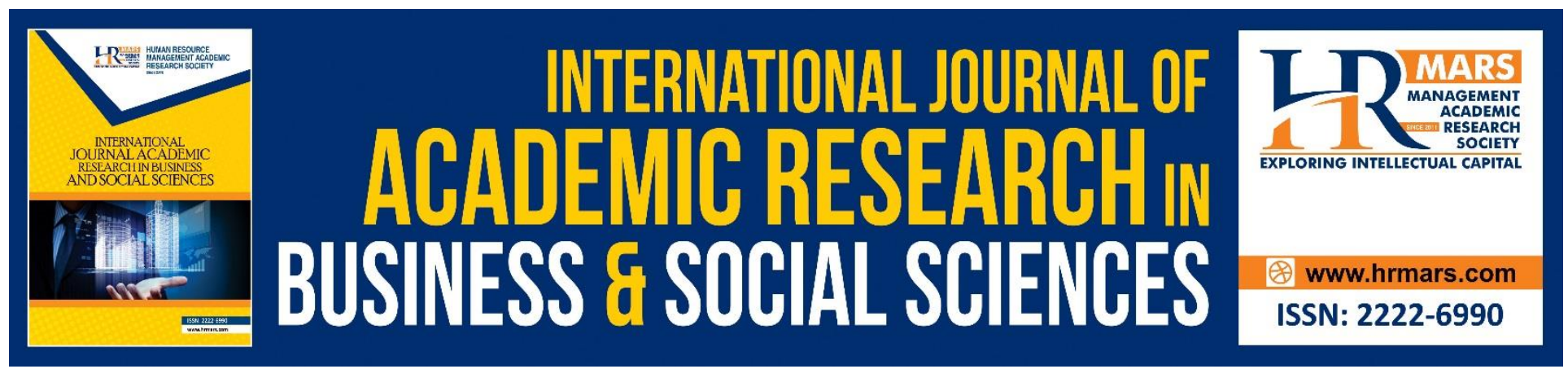

\title{
The Impact of Corporate Social Responsibility and Coprorate Identity Management on Image and Performance: The Case of City Hotels in Klang Valley, Malaysia
}

Norzalita Abd Aziz

To Link this Article: http://dx.doi.org/10.6007/IJARBSS/v10-i10/7839

DOI:10.6007/IJARBSS/v10-i10/7839

Received: 10 August 2020, Revised: 07 September 2020, Accepted: 27 September 2020

Published Online: 26 October 2020

In-Text Citation: (Abd Aziz, 2020)

To Cite this Article: Abd Aziz, N. (2020). The Impact of Corporate Social Responsibility and Coprorate Identity Management on Image and Performance: The Case of City Hotels in Klang Valley, Malaysia. International Journal of Academic Research in Business and Social Sciences. 10(10), 662-681.

Copyright: (C) 2020 The Author(s)

Published by Human Resource Management Academic Research Society (www.hrmars.com)

This article is published under the Creative Commons Attribution (CC BY 4.0) license. Anyone may reproduce, distribute, translate and create derivative works of this article (for both commercial and non-commercial purposes), subject to full attribution to the original publication and authors. The full terms of this license may be seen at: http://creativecommons.org/licences/by/4.0/legalcode

Vol. 10, No. 10, 2020, Pg. 662 - 681

http://hrmars.com/index.php/pages/detail/IJARBSS

JOURNAL HOMEPAGE

Full Terms \& Conditions of access and use can be found at http://hrmars.com/index.php/pages/detail/publication-ethics 


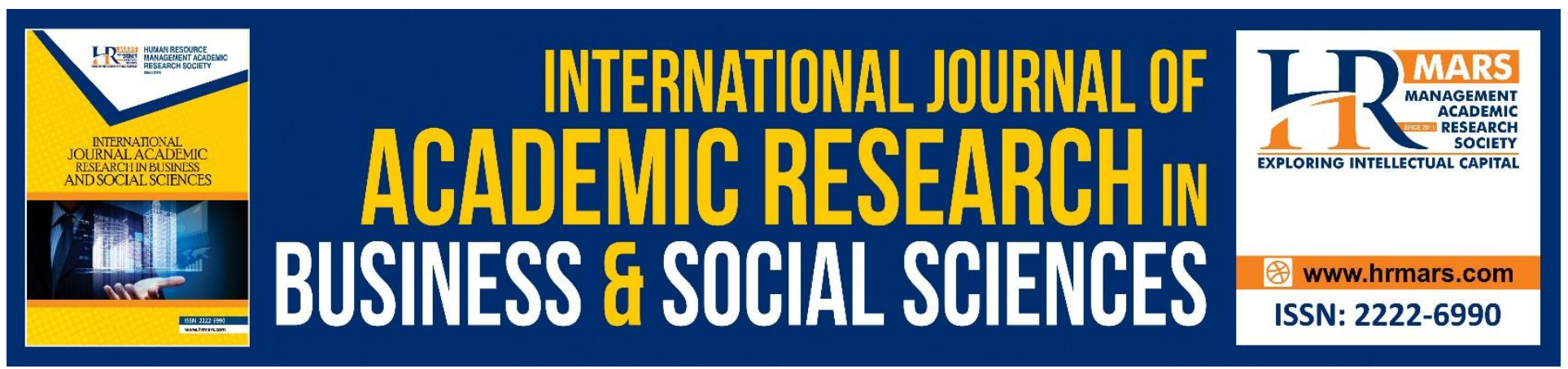

\title{
The Impact of Corporate Social Responsibility and Coprorate Identity Management on Image and Performance: The Case of City Hotels in Klang Valley, Malaysia
}

\author{
Norzalita Abd Aziz \\ Graduate School of Business, Universiti Kebangsaan Malaysia \\ Email: eita@ukm.edu.my
}

\begin{abstract}
CSR can be seen as both an investment and marketing strategy for an organization. Connecting with today's customer is harder than ever. CSR can help boost an organizations' image and perception whilst relatively increasing brand image and recognition. The purpose of this research is to illustrate the importance of Corporate Social Responsibility (CSR) and its effect on hotels in Malaysia. This study explored the relationship between Corporate Identity Management comprises of Mission \& Value Dissemination (MVD), Consistent Image Implementation (CII), Visual Identity Implementation (VII), Corporate Social Responsibility (CSR) and Corporate Image Attractiveness (CIA). The study also investigated the role of the CSR integration in the linkage between CIM and Corporate Image Attractiveness. From an analysis of usable data from 80 city hotels, this study found that Mission \& Value Dissemination (MVD) and Corporate Social Responsibility influenced directly the Corporate Image of Hotels. The integration of the CSR did not seem to moderate the influence of MVD, CII, VII on hotels' Corporate Image Attractiveness (CIA). The study findings showed that $\mathrm{CIA}$ has a direct influence on Corporate Performance (CP). The profiles of hotels located in Klang Valley, Malaysia constructed using characteristics in terms of its size, age in operations, hotel class, no. of employees, percentage employees experienced in marketing, estimated no. of customers in a month and active marketing/ business plan, which can be used for the future research. The output of the research is used in developing the framework of recommendations for CSR implementation and its usefulness.
\end{abstract}

Keywords: Corporate Social Responsibility (CSR), Corporate Identity Management (CIM), Image, Performance, City Hotels

\section{Introduction}

Nowadays, many private institutions or semi government bodies are competing for business on price, level of service or quality as their competitive advantage. Non-profit organizations often use value of service, efficiency or societal benefit to engender their competitive advantage. Today, governments, investors, consumers and even employees have become more sophisticated and more aware of 
INTERNATIONAL JOURNAL OF ACADEMIC RESEARCH IN BUSINESS AND SOCIAL SCIENCES Vol. 10, No. 10, 2020, E-ISSN: 2222-6990 @ 2020 HRMARS

excellent corporate behaviour, or lack thereof. In this new business environment, the most valuable asset is company reputation and CSR has become one of the key components of corporate reputation. CSR is generally used to illustrate a business's endeavours to achieve sustainable outcomes by committing to good business performance and standards (Lin et al. 2020; Clayton, 2011). While the notion or concept may be comparatively new in the region, the actual practices and related policies are not. In a general sense, social responsibility is management's acceptance of the commitment to consider consumer satisfaction, profit and the societal well-being of equal value in evaluating a firm's performance. It is the appreciation or recognition that businesses must be concerned with the qualitative dimensions of consumer, employee and societal benefits, as well as the quantitative measures of sales and profits, by which business performance is usually considered.

In Malaysia, the concept of CSR is at an evolutionary stage, and some companies still associate the term CSR with philanthropy or generosity, (perhaps this attitude is embedded culturally, as many Malaysians believe in not publicizing their charitable acts). For these companies, CSR or at least their philanthropic version of CSR is merely a component of their corporate culture and looked upon as charity work. Their CSR activities usually consist of sponsorships, donations, and community service activities such as building schools, hospitals, roads and parks. Despite its long history, the evolution of the concept, and the increasing of CSR worldwide, a universally accepted definition of CSR does not exist. Different terms in the literature describe the phenomena related to corporate responsibility in society such as corporate social responsibility, corporate citizenship, corporate philanthropy, corporate giving, community development and corporate sustainability (Kotler \& Lee, 2005).

CSR is the ethical conduct of a company towards society, management acting responsibly in its relationships with other stakeholders who have a legitimate or genuine interest in the business, and the ongoing commitment by a business to behave ethically and contribute to economic growth while developing the quality or class of life of the personnel and their families as well as of the local community and society at large (The World Business Council). This study aims to understand and explore the roles play by Corporate Identity Management (CIM) and Corporate Social Responsibility (CSR) and its effects on hotels in Malaysia. In order to do so, there are three main objectives constructed as the following:

i)To determine which factors of CIM that will influence the Corporate Image among hotels ii) To examine the influence of Corporate Social Responsible on Corporate Image among hotels. iii) To identify the moderating role of CSR towards the relationship between CIM and Corporate Image.

Corporate Social Responsibility programmes can generate favourable purchase intent or product choice among the sponsoring firm's customers and favourable customer attitudes towards the sponsoring firm (Chan and Saad 2019; Al Choiri et al., 2019) Despite the growing body of literature in this context but there is still lack of studies that examines the effect of CSR on companies' corporate image and identity as well as company success in terms of performance (Lin et al. 2020; Sen and Bhattacharya, 2001) especially in the hospitality industry. CSR provides a competitive advantage and assists in enhancing positive corporate image and reputation. Company needs to identify CSR activities that best reflect their particular industry in the marketplace (Tong and Wong, 2016). In 
INTERNATIONAL JOURNAL OF ACADEMIC RESEARCH IN BUSINESS AND SOCIAL SCIENCES Vol. 10, No. 10, 2020, E-ISSN: 2222-6990 @ 2020 HRMARS

addition, there remains a significant gap in the testing and application of the relationship between corporate image, company performance and CSR in multi-industry contexts, such as for companies of different sizes, from different industries, and with different marketing budgets (Vlachos et al., 2009).

As the demand for travel and tourism is keep increasing, thus city tourism has become greatly important especially with the expansion of low cost and non-frill airlines. Thus, this creates a significant demand for tourism product and services such accommodations in the urban tourism sector. Besides leisure, tourists that visit cities have several purposes such as business, conferences, shopping (Ashworth and Page, 2011). This study can assist hotels in Klang Valley, Malaysia to recognize and understand the relationship and importance of Corporate Social Responsibilities (CSR) and Corporate Identity Management (CIM). Klang Valley is chosen because it is an area in which is centred in Kuala Lumpur (Capital of Malaysia) and includes several adjoining cities and towns in the state of Selangor. This study hopes to assist organizations to choose how to develop the market and target the product, based on the knowledge concerning the effectiveness and contribution of CSR and CIM in promoting the organization. This will also help in the correct product placement at the right time and at the right place to the correct person.

\section{Literature Review}

\section{Corporate Social Responsibility (CSR)}

CSR adopts a position that builds both shareholder value and work holder value in order to deliver "sustainable growth for the future". CSR is "the ability of a company to incorporate its responsibility to society to develop solutions for economic and social problems. Whilst there is no universally acknowledged definition (Weber, 2008), CSR generally refers to a firm's activities, organizational processes, and type in relation to its perceived societal or stakeholder obligations (Wood, 1991; Sen and Bhattacharya, 2001). Much has been written on what comprises CSR and many viewpoints exist. Corporate social responsibility can be defined as the actions of a firm to benefit society beyond the requirements of the law and the direct interests of the firm (McWilliams and Siegel, 2001). Social responsibility is also the expectation that businesses or individuals will strive to improve the overall welfare of society (Thomas, 2000). Corporate social responsibility as open and visible or transparent business practices that are based on ethical values and admiration for the community, employees, the environment, shareholders and other stakeholders (Said et al., 2009). CSR is defined as: "The level and extent to which businesses presume the economic, legal, ethical, and discretionary responsibilities forced or imposed on them by their various stakeholders" (Maignan et al., 1999).

According to Galbreath (2010), the conceptualization of the accountabilities of firms has remained a consistently accepted approach, particularly with respect to empirical study. His conceptualization comprises four social responsibilities, i.e. the economic and financial responsibility to engender profit, offer jobs and produce products that a consumer wants; the legal task to comply with local, state, federal and relevant international laws; the ethical and moral responsibility to meet other social expectations; not written as law such as avoiding harm and respecting people's moral rights; and the discretionary responsibility to meet additional behaviours and activities that society finds attractive, such as providing employee benefits - training and better salaries. CSR is a complex and diverse term representing business standards focusing on the long-term nature of business itself and 
INTERNATIONAL JOURNAL OF ACADEMIC RESEARCH IN BUSINESS AND SOCIAL SCIENCES Vol. 10, No. 10, 2020, E-ISSN: 2222-6990 @ 2020 HRMARS

increasing value for shareholders. The observance of CSR principles is a prerogative for all company employees (Kim et al., 2016) and not only for top management. This particular style of working gratifies and benefits all parties - the government, employees and their family members, consumers, local communities and shareholders. In contrast to other industries, CSR in service industry means managing business responsibly and sensitively for long-term success.

Corporate social responsibility also means at a basic level that "corporate activity should be motivated in part by a concern for the welfare of some non-owners, and by an underlying commitment to basic principles such as integrity, fairness and respect for persons" (Donaldson, 2005). In order to build up a successful company, three stages of CSR leadership are required - CSR decision, CSR adoption and CSR commitment. These capabilities are important for any CSR leader to expand or develop. One might visualize and predict that some of the skills might also be dispersed across or within a highly successful CSR team or division, and that in an organization with a highly developed CSR application, all leaders would have each of the basic skills, and would be able to use them properly and with the best timing (Knight and Paterson, 2018; Kakabadse et al, 2001).

In today's marketing world, the companies have to be caring and they should look after the welfare of their customers and society. In the last decade, companies have failed to take blame for the effects of their corporate conduct or performance on society, especially when these effects go ahead of or beyond the firms' direct commercial interests. As a result, an increasing number of companies, both small and big, have developed corporate social responsibility (CSR) programmes (Maignan \& Ralston, 2002). As a type or category of CSR, cause-related marketing (CRM) has received abundance of corporate interest. This is because CRM might have an optimistic and positive effect on consumer behaviour and corporate reputation (Sageder et al., 2018). According to Moir (2001), whether or not business should undertake CSR, and the forms that responsibility should take, depends upon the economic perspective that is adopted by the firm. The success of CSR in any organization is dependent on its corporate social orientation and values.

The benefits of determined commitment to CSR include a strong reputation and better corporate brand recognition, being represented as responsible by stakeholders, sustainable product brand loyalty and enhanced government and community relations. CRM is the process of formulating and implementing marketing activities that are characterized by an offer from the firm to contribute a specified amount to a designated cause when customers engage in revenue-providing exchanges that satisfy organizational and individual objectives (Varadarajan \& Menon, 1988). Cause-related marketing is to be positioned in the context of corporate social responsibility (CSR). Within this impression of CSR, CRM is a specific or explicit marketing activity in which the firm promises its consumers to contribute company resources to a valuable cause for each product or service sold. A CRM campaign aims at two goals - to support and sustain a social cause and to improve marketing performance For the participating cause, cause-related marketing programmes accumulate rewards such as new sources of much-needed funds, and finely tuned public awareness while consumers gain a sense of supplementary and additional perceived value to their purchase and rewarding their philanthropic needs of the self by serving society (Polonsky \& Wood, 2001). CSR is extremely useful in corporate identity- building because of its ability to facilitate corporate image attractiveness and thereby increase competitive advantage and overall company performance. Finally, yet importantly, 
INTERNATIONAL JOURNAL OF ACADEMIC RESEARCH IN BUSINESS AND SOCIAL SCIENCES Vol. 10, No. 10, 2020, E-ISSN: 2222-6990 ๑ 2020 HRMARS

CSR can be concluded as a way to bolster image prior to a crisis. One way an organization can protect against the backlash of crises is through practicing CSR practices. Haigh and Brubaker (2010) defined CSR as "the social responsibility of business encompasses the economic, legal, ethical and discretionary expectations that society has of organizations at a given point in time". CSR activities can include providing money to charities or being a good corporate citizen.

It is important to consider how the execution of CSR cannot be a one-person show. Indirectly, it takes commitment from managers below the top-level executive to implement CSR policies and practices. Top-level executives with strong constituent group values and those viewed as inspirational tended to produce assistant managers who shared similar values (Knight and Paterson, 2018; Waldman et al., 2006). The business plan under CSR should be integrated with the social and environmental concerns related to the business of the company. According to Sheikh and Beise-Zee (2011), a company might need to clarify what they stand for, how corporate responsibility is carried out, and how people profit from such actions. In marketing research, CSR can be seen as a homogeneous and standardized concept that is applied and communicated meticulously across industries and company sizes (Maignan and Ferrell, 2004).

Although some research suggests that communicating about CSR activities does not always reflect positively on a company (Sen and Bhattacharya, 2001), other research supports the approach of cause-related marketing as a means to develop corporate performance and concurrently help worthy causes based on compassionate grounds (Varadarajan and Menon, 1988). However, implementing such policies requires communication with the stakeholders, not only to convince them that the company is serious about its CSR strategies but also to guarantee that those strategies contribute to the corporate image and brand equity (Jahdi and Acikdilli, 2009).

Since empirical or experimental research has found links between CSR and corporate identity, CSR has been included in excellence models impacting company reputation and corporate image. More companies than ever are endeavouring to influence CSR associations, with CSR reports "filling web pages and brochures" (Snider et al., 2003), while, not surprisingly, with diverse and mixed success in improving firms' status, reputation and monetary success in the marketplace (Sen and Bhattacharya, 2001). Regardless of the fast growing research in the field of CSR and its assessable output on company performance, contradictions and inconsistencies remain related to how and under which conditions CSR leads to the development of corporate image, competitive advantage and its relationship to company's performance (Arendt \& Brettel, 2010; Vlachos et al., 2009; Zairi and Peters, 2002).

\section{Corporate Identity Management and Reputation}

Corporate identity deals with the impressions, image and personality that an organization presents to its stakeholders in order to differentiate itself and create a unique position in the environment in which it operates (Melewar, Sarstedt and Hallier, 2012). Simoes and Dibb. (2008) suggest that there is a common internal platform for identity management that reflects consistent messages about the organization so that a reputable corporate image is transmitted across audiences. Since the notion of corporate identity is linked to a range of related concepts that we refer to as external determinants of corporate image, such as reputation and branding, for our purpose, CIM comprises the internal 
INTERNATIONAL JOURNAL OF ACADEMIC RESEARCH IN BUSINESS AND SOCIAL SCIENCES Vol. 10, No. 10, 2020, E-ISSN: 2222-6990 @ 2020 HRMARS

efforts by which a company works to identify itself. The objective of corporate identity management (CIM) is to establish a favourable reputation with an organization's stakeholders in respect of the services, to work for the organization or to invest in it (Balmer, 1995; Van, 1995).

Corporate reputation is a snapshot that reunites the numerous images of a company held by all its constituencies or population. It indicates the overall attractiveness or magnetism of the company to employees, consumers, investors, suppliers and local communities. Therefore, corporate reputation is defined as the manifestation of an organization over time as seen through their belief and words on brand performance as well as satisfaction (Buil, Catalan and Martinez, 2016; Gotsi and Wilson, 2001). They add that reputation embodies the history of other peoples' experience with a service provider related to several key characteristics to the concept of corporate reputation, such as a cognitive feature of an industry or philanthropic criteria in judging a company and its future prospects and views. Therefore, the following definition is proposed as a corporate reputation based on the stakeholder's general assessment of a company over time. This evaluation is based on the stakeholder's direct experience and familiarity with the company, any other form of communication, statement and symbolism that provides information about the firm's actions and/or a comparison with the actions or accomplishment of other leading rivals (Gotsi and Wilson, 2001).

\section{Corporate Image Attractiveness}

The definitions of corporate image at different conceptualizations are visible in literature. Fombrun (1996) defines corporate image as "the image an audience has of an organisation through the accumulation of received messages". Corporate Image is manufactured and, hence, is not a true reflection of the company's reality (Gotsi and Wilson, 2001). They stress that the original meaning of image has been equated with a visual representation of reality, now it commonly refers to a fabrication or public impression created to appeal to the audience rather than to reproduce reality. In addition, the term 'image' represents the sum of beliefs, attitudes and impressions that a person or group has for an object. Corporate image is significant in order to produce quality company/hotels in Malaysia. Advertising can be one of the reasons for their being superseded, even though they carry a five star name, such as Holiday Villa or Holiday Inn. However, it seems these hotels are far behind compared to Ritz-Carlton, JW Marriott, St. Regis, Sheraton and others in-line with these hotels. Therefore, the hotel's name must be parallel when delivering the best corporate image, which includes staff behaviour, cleanliness and tidiness, time management, architecture, etc. The corporate image is the result of all experiences, impressions, beliefs, feelings and knowledge that people have acquired related to a company (Worcester, 2009). Corporate image attractiveness can be defined as the attractiveness of the corporate image, as perceived by its various audiences (Bhattacharya and Sen, 2003). Many studies draw the link between favorable corporate identity towards superior business performance (Brown et al., 2006; Bharadwaj and Menon, 1993), 
INTERNATIONAL JOURNAL OF ACADEMIC RESEARCH IN BUSINESS AND SOCIAL SCIENCES Vol. 10, No. 10, 2020, E-ISSN: 2222-6990 @ 2020 HRMARS

\section{Hypotheses and Conceptual Framework}

Figure 1 shows the research model of this study. The framework assumes that CIM and CSR have direct and indirect link with firm innovativeness.

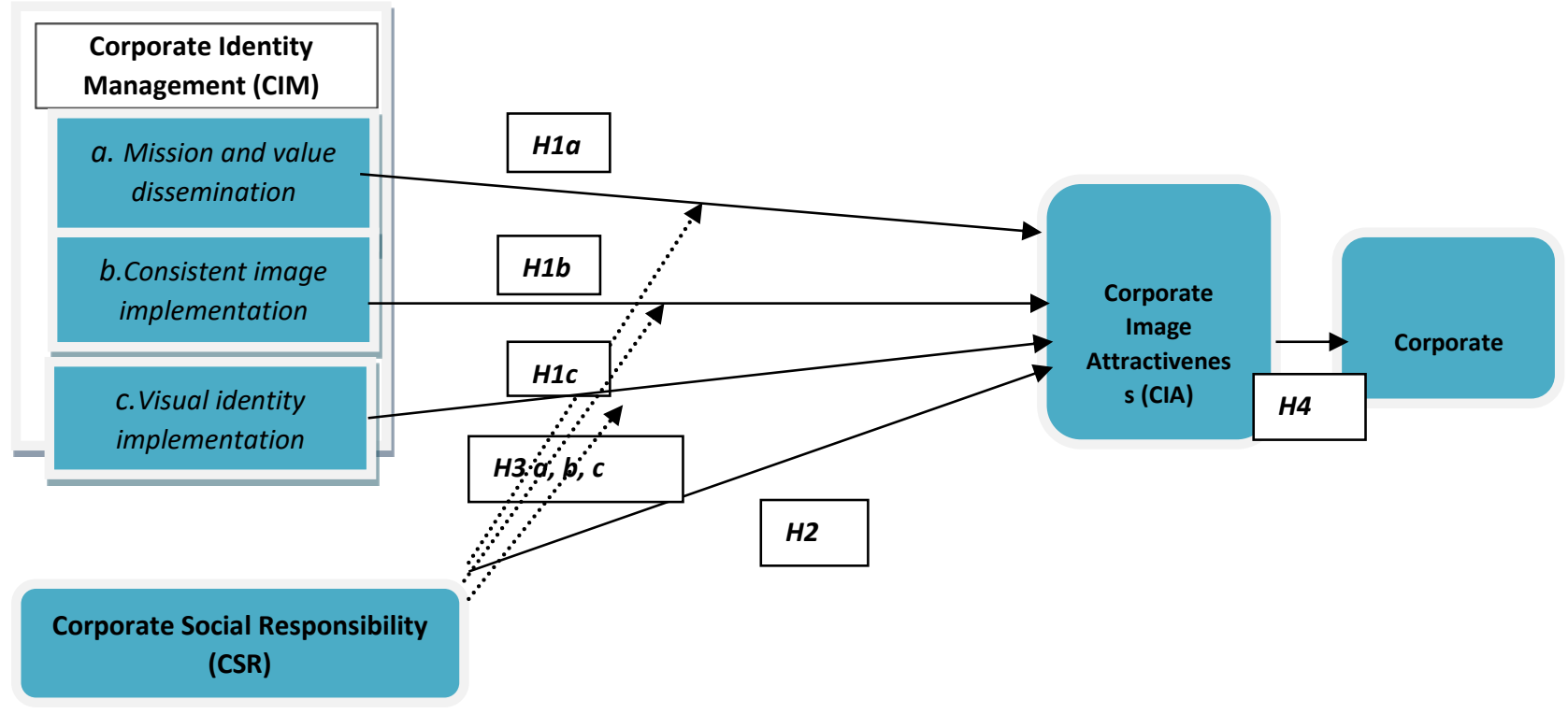

Figure 1.0: The research conceptual model

The CIM model is based on Simoes et al. (2005) and Balmer (1995) has been chosen as part of the theoretical framework. An internally controlled reputation-building process is a prerequisite for acquiring a favourable corporate image (Fombrun, 1996; Simoes and Dibb, 2008). It has been extended by including the Corporate Image Attractiveness. Therefore, drawing on the CIM model, it has been classified with three items: MVD, CII and VII, and tests the impact with the existence of Corporate Social Responsibility (CSR) in order to execute the best of Corporate Image.

Based on the above literature review, this study suggests the following hypotheses in the context of hotels in Malaysia;

H1a: Mission and Value Dissemination (MVD) has an impact on Corporate Image Attractiveness.

H1b: Consistent Image Implementation (CII) has an impact on Corporate Image Attractiveness.

H1c: Visual Identity Implementation (VII) has an impact on Corporate Image Attractiveness.

H2: $\quad$ CSR activities or programmes have an impact on Corporate Image Attractiveness

H3a: CSR initiatives moderate the relationship of Mission and Value Dissemination (MVD) with Corporate Image Attractiveness

H3b: CSR initiatives moderate the relationship of Consistent Image Implementation (CII) with Corporate Image Attractiveness

H3c: $\quad$ CSR initiatives moderate the relationship of Visual Identity Implementation (VII) with Corporate Image Attractiveness

H4: Corporate Image Attractiveness (CIA) will influence the Corporate Performance of the organisation. 
INTERNATIONAL JOURNAL OF ACADEMIC RESEARCH IN BUSINESS AND SOCIAL SCIENCES Vol. 10, No. 10, 2020, E-ISSN: 2222-6990 @ 2020 HRMARS

\section{Methodology \\ Research Design}

Database for this research was obtained from Malaysia Association of Hotels. For the purpose of this study, 3 stars hotels and above were chosen which located in City Centre and suburb of Kuala Lumpur. A total number of 149 hotels and service apartments were identified for the actual survey and selected from the listing. A total of 80 hotels responded to this study, which represents a response rate of 54 per cent. Since the main objective of this study is to clarify the domain constructs, the unit of analysis is conducted at the organizational level of analysis. Therefore, the top management or the senior executives or managers' perceptions of the study variables are measured. To be more specific, questionnaires were distributed to the Financial Manager, Public Affairs \& Communication Manager and Operation Manager of each hotel. These people are regarded as the main source of information because they are directly responsible for planning and management of the company. The survey was conducted through self-administered questionnaires, which were distributed to the respective hotels.

The data collection instrument is a structured questionnaire, which was first developed and pretested among a small group of respondents, who are academics and have significant expertise in marketing and hospitality industry. A questionnaire with seven parts was designed as shown in Table II. Part A consisted of 5 items that measure CIM on Mission and Value Dissemination (MVD). Part B highlighted Consistent Image Implementation (CII) with 8 items followed by 4 items for part $\mathrm{C}$ on Visual Identity Implementation (VII). All of the items were adopted from Simoes and Dibbs (2008). Part D explains the Corporate Social Responsibility (CSR) with 16 items that were adopted from Lichtenstein, Drumwright and Braig (2004) and Potluri, Batima, and Madiyar (2010). Part E highlighted Corporate Image Attractiveness (CIA), which was adopted by Bhattacharya and Sen (2003), with 6 items. Part F, the Corporate Performance (CP) was measured using items from Aziz and Yasin (2010). The scale used for the questionnaire was a 6-point Likert-type scale from ' 6 ' for 'strongly agree' to ' 1 ' strongly disagrees. The six-point scale was used to anchor each item statement was chosen in order to avoid the clustering of responses at the neutral point and remain non-committal (Quee, 2002). The last part of the questionnaire included several questions, which were intended to identify the personal and organizational information variables, namely, age of organization, and percentage of company involvement in marketing and existence of business plan.

\section{Measures}

In order to ascertain whether the measures retained construct validity (i.e. measure what they are supposed to) an exploratory factor analysis using principal components and varimax rotation technique was conducted to examine the underlying dimension of market orientation and market competency. In determining the factor/s, common decision rules employed in empirical research were applied: (i) minimum eigenvalue of 1 (ii) KMO measure of sampling adequacy greater than 0.5 and the Bartlett's test of sphericity should be significant which indicate that the items for consumption factor are appropriate for factor analysis. (iii) minimum factor loading of 0.5 for each indicator variable. The cut-off value of 0.5 and higher is assigned such that only items with loadings of at least 0.50 are retained in order to obtain a power level at $80 \%$ at 0.05 significant levels (Hair et al., 1998). Items with loadings exceeding 0.50 on two or more dimensions are removed and have to retest. (iv) simplicity of factor structure, and ( $v$ ) exclusion of single item factor structure. $v$ ) reliability 
INTERNATIONAL JOURNAL OF ACADEMIC RESEARCH IN BUSINESS AND SOCIAL SCIENCES Vol. 10 , No. 10, 2020, E-ISSN: 2222-6990 @ 2020 HRMARS

analysis is carried out to eliminate items that are not strongly related to other items in the construct and construct reliability was assessed using Cronbach's alpha. As suggested by Nunnally (1978), the reliability of a construct between 0.6 and 0.8 is acceptable. The summary of factor analysis results (KMO \& variance), reliability test and descriptive statistic are shown below (please refer Table 2)

\section{Findings}

Table 1 show the study sample comprises of 80 hotels, which vary on characteristics such as company, age of company, and number of employees.

Table 1: Description of Study Sample

\begin{tabular}{|c|c|c|}
\hline$N=80$ & Frequency & Percentage \\
\hline \multicolumn{3}{|l|}{ Hotels Class } \\
\hline Boutique & 14 & 17.5 \\
\hline Apartment & 10 & 12.5 \\
\hline 3 star & 16 & 20.0 \\
\hline 4 star & 25 & 31.3 \\
\hline 5 star & 13 & 16.3 \\
\hline 6 star & 2 & 2.5 \\
\hline \multicolumn{3}{|c|}{ Collate Info on Customers and marketplace } \\
\hline Yes & 62 & 77.5 \\
\hline No & 18 & 22.5 \\
\hline \multicolumn{3}{|c|}{$\begin{array}{l}\text { Hotel has Business/Marketing } \\
\text { Plan }\end{array}$} \\
\hline Yes & 64 & 80.0 \\
\hline No & 16 & 20.0 \\
\hline \multicolumn{3}{|l|}{ Age of Hotel } \\
\hline Less than 5 years & 18 & 22.5 \\
\hline $5-9$ years & 24 & 30.0 \\
\hline $10-14$ years & 27 & 33.8 \\
\hline 15 years and above & 11 & 13.8 \\
\hline \multicolumn{3}{|l|}{ No. of Employees } \\
\hline Less than 5 & 0 & .0 \\
\hline $5-10$ & 2 & 2.5 \\
\hline $11-25$ & 14 & 17.5 \\
\hline $26-50$ & 21 & 26.3 \\
\hline Over 50 & 43 & 53.8 \\
\hline \multicolumn{3}{|c|}{ Percentage Experienced in Marketing } \\
\hline $0-20 \%$ & 6 & 7.5 \\
\hline $21-40 \%$ & 18 & 22.5 \\
\hline $41-60 \%$ & 22 & 27.5 \\
\hline $61-80 \%$ & 19 & 23.8 \\
\hline $81-100 \%$ & 15 & 18.8 \\
\hline
\end{tabular}


INTERNATIONAL JOURNAL OF ACADEMIC RESEARCH IN BUSINESS AND SOCIAL SCIENCES Vol. 10, No. 10, 2020, E-ISSN: 2222-6990 @ 2020 HRMARS

\begin{tabular}{|l|c|c|}
\hline \multicolumn{1}{|c|}{$\mathbf{N = 8 0}$} & Frequency & Percentage \\
\hline Years of Working (respondent) & \multicolumn{2}{|c|}{} \\
\hline Less than 1 year & 1 & 1.3 \\
\hline $1-5$ years & 21 & 26.3 \\
\hline $5-10$ years & 25 & 31.3 \\
\hline $11-15$ years & 9 & 26.3 \\
\hline $16-20$ years & 3 & 11.3 \\
\hline More than 20 years & 7 & 3.8 \\
\hline Total number of customers per month (estimated) & 8.8 \\
\hline$>100$ customers & 13 & 16.3 \\
\hline$>250$ customers & 23 & 28.8 \\
\hline$>500$ customers & 37 & 46.3 \\
\hline$>1000$ customers & 73 & \\
\hline
\end{tabular}

The multiple regression analysis (stepwise method) is performed to test empirically the hypotheses postulated in the study. It enables us to better assess the contribution of independent variables to Corporate Image Attractiveness. Additional procedures are employed to detect outliers and not to violate the assumptions of the multiple regressions.

Table 2: Summary of Factor Analysis, Reliability Test, Mean and Standard Deviation

\begin{tabular}{|c|c|c|c|c|c|}
\hline & $\begin{array}{c}\text { Cronbach's } \\
\text { Alpha }\end{array}$ & $\begin{array}{c}\text { F.A } \\
\text { KMO }\end{array}$ & $\begin{array}{c}\text { F.A. } \\
\text { \% Cum. Of } \\
\text { Variance }\end{array}$ & Mean & SD \\
\hline $\begin{array}{c}\text { Corporate Identity Management } \\
\text { (CIM) }\end{array}$ & 0.943 & 3 & 4.593 & 0.001 & 0.890 \\
\hline$*$ Mission and Value Dissemination \\
(MVD) & 0.910 & 0.837 & 60.3 & 4.627 & 0.959 \\
\hline$*$ Consistent Image Implementation \\
$\begin{array}{c}\text { (CII) } \\
\text { * Visual Identity Implementation (VII) }\end{array}$ & 0.915 & 0.828 & 53.7 & 4.553 & 0.870 \\
\hline $\begin{array}{c}\text { Corporate Social Responsibility } \\
\text { (CSR) }\end{array}$ & 0.949 & 0.920 & 63.0 & 4.387 & 0.917 \\
\hline $\begin{array}{c}\text { Corporate Image Attractiveness } \\
\text { (CIA) }\end{array}$ & 0.886 & 0.806 & 50.1 & 4.413 & 0.971 \\
\hline Corporate Performance (CP) & 0.969 & 14 & 4.121 & 0.006 & 1.100 \\
\hline
\end{tabular}


INTERNATIONAL JOURNAL OF ACADEMIC RESEARCH IN BUSINESS AND SOCIAL SCIENCES Vol. 10, No. 10, 2020, E-ISSN: 2222-6990 @ 2020 HRMARS

Table 3: Regression Analysis - The Influence of CIM (MVD, CII, VII) and CSR on Corporate Image Attractiveness

\begin{tabular}{|l|l|l|l|l|l|l|}
\hline $\begin{array}{l}\text { Dependent } \\
\text { Variable }\end{array}$ & Independent Variables & $\begin{array}{l}\text { Unstd. } \\
\text { Beta }\end{array}$ & $\begin{array}{l}\text { Std. } \\
\text { Beta }\end{array}$ & t & Sig. & VIF \\
\hline CIA & Constant & 0.163 & & & & \\
& CSR & 0.501 & 0.473 & 5.030 & 0.000 & 1.99 \\
& MVD & 0.444 & 0.438 & 4.660 & 0.000 & 1.19 \\
\hline R $=0.862 \quad$ R Square $=0.743 \quad F=111.551$ & Sig. $F=0.000$ \\
\hline
\end{tabular}

As stated earlier, hypothesis $\mathrm{H} 1 \mathrm{a}, \mathrm{H} 1 \mathrm{~b}, \mathrm{H} 1 \mathrm{c}$ and $\mathrm{H} 2$ have a direct influence on $\mathrm{CIA}$. Table 3 shows that CSR and MVD, with coefficients of 0.501 and 0.444 , respectively, are both significantly related to $\mathrm{CIA}$ at the $\mathrm{p}<0.05$ level. Thus, $\mathrm{H} 1 \mathrm{a}$ and $\mathrm{H} 2$ are supported by the coefficients. Based on the above values, it is proved that CSR and MVD play major roles in order to produce the best CIA. For example, many hotels are well known after their involvement in CSR because CSR is about managing business in a manner that has an overall positive impact on society at large, in addition, it is essential for the longterm sustainability of a firm. While in order to achieve the highest corporate image attractiveness, a company must have a very well-defined mission to put them on top or parallel with other thriving companies. Employees also play a major role when they view themselves as partners in charting the direction of the company and are aware of the relevant values. Hence, with the combination of CSR and MVD, simultaneously, CIA can demolish the competition and place them as a first-class and highquality company.

From this, it can be deduced that CSR is more influential in explaining CIA with a beta value of 0.473, which is higher than the 0.438 for MVD, since it is clearly affirmed that investment in CSR is integrated as an important dimension of a company's business strategy. Essentially, CSR is the deliberate or planned inclusion of public interest in corporate decision making, and the honouring of a triple bottom line, which is people, planet and profit. Furthermore, pursuing CSR in business practices can help any business enhance reputation and standing in building trust from stakeholders, generating sales, boosting enthusiasm and also product innovation or modernization.

Table 4: The Moderating Effect of CSR as a moderator in the relationship between CII, VII and MVD

\begin{tabular}{|c|c|c|c|}
\hline Independent Variables & Std. Beta 1 & Std. Beta 2 & Std. Beta 3 \\
\hline MVD & 0.397 & $\mathbf{0 . 3 9 4 ^ { * }}$ & $1.188^{*}$ \\
CII & $\mathbf{0 . 3 7 4 *}$ & 0.164 & 0.324 \\
VII & 0.104 & -0.078 & -0.917 \\
CSR & & $\mathbf{0 . 4 3 6 ^ { * }}$ & $\mathbf{0 . 6 1 2 ^ { * }}$ \\
CIICSR & & -0.292 \\
VIICSR & & 1.334 \\
MVDCSR & -1.310 \\
\hline \multicolumn{2}{|c|}{} \\
\hline
\end{tabular}


INTERNATIONAL JOURNAL OF ACADEMIC RESEARCH IN BUSINESS AND SOCIAL SCIENCES Vol. 10, No. 10, 2020, E-ISSN: 2222-6990 @ 2020 HRMARS

Table 4 shows the hierarchical regression result, the CSR as a moderator in the relationship between factors of CIM (MVD, CII and VII) and CIA. The hierarchical regression tested hypotheses $\mathrm{H} 3 \mathrm{a}, \mathrm{H} 3 \mathrm{~b}$, and $\mathrm{H} 3 \mathrm{c}$. The hierarchical regression shows that CSR did not moderate the relationship between MVD, CII, VII and CIA. Thus, all the hypotheses were rejected. Instead, CSR has direct relationship to hotel's CIA. CSR efforts and the corresponding expenses may be considered as a luxury item in the firm's profit and loss statement meaning that only financially robust companies can afford them. This reasoning suggests that in a firm with limited financial resources, CSR as an investment may not act as a moderator in strengthening the effect of CIM initiatives and its outcomes. Therefore, CSR does not strengthen the relationship between of CIM and corporate image. A firm's financial ability and its willingness to allocate such resources for marketing can hugely impact its corporate identity activities, acting as an impetus between the corporate identity activities and corporate brand relationships. Firms with substantial financial surplus will most probably spend on marketing and, conversely, it is often the first to be cut in the case of financial trouble.

Table 5: Regression Analysis - The Influence of CIA on Corporate Performance

\begin{tabular}{|l|l|l|l|l|l|l|}
\hline $\begin{array}{l}\text { Dependent } \\
\text { Variable }\end{array}$ & $\begin{array}{l}\text { Independent } \\
\text { Variables }\end{array}$ & $\begin{array}{l}\text { Unstd. } \\
\text { Beta }\end{array}$ & $\begin{array}{l}\text { Std. } \\
\text { Beta }\end{array}$ & t & Sig. & VIF \\
\hline CP & $\begin{array}{l}\text { Constant } \\
\text { CIA }\end{array}$ & $\begin{array}{l}-0.060 \\
0.948\end{array}$ & 0.837 & 13.495 & 0.000 & 1.000 \\
\hline
\end{tabular}

Hypothesis 4 proposes that $\mathrm{CIA}$ has a direct influence on Firm Performance. Hence, Table 5 shows that the coefficient for $\mathrm{CIA}$ with a value of 0.948 is statistically significantly related to $\mathrm{CP}$ because the $p$ value of 0.000 is less than the 0.05 level. Thus, Hypothesis 4 , which states that $\mathrm{CIA}$ has a direct influence on $\mathrm{CP}$ and the impact of $\mathrm{CIA}$ is the crucial factor that will definitely influence the hotel performance mostly in the Klang Valley, is supported.

As $\mathrm{CIA}$ is primarily hospitality service oriented, it can directly enhance a firm's performance if it really maintains the best services including employee courtesy, cleanliness, uniform, food, etc. In order to maintain the best result for FP, the industry must be satisfied with the value enhancement for customers, maintain the level of customer loyalty, the number of new customers, success of their products and services, forecast of operating results in the next couple of years and, finally, the growth of the company. All these have been measured in the questionnaires proposed by the researcher in this empirical study. Therefore, Hypothesis 4 is significant at 0.000 and it is proved that $\mathrm{CIA}$ is key factor that influences CP.

\section{Discussion \& Conclusion}

\section{Theoretical Implications}

This study examined the factors that influence hotels' involvement in CIM and CSR activities. The findings supported previous studies such as Vlachos et al (2009), Sen and Bhattacharya (2001). Press coverage discussing CSR activities enhanced individuals' perceptions of a firm's standing vis-à-vis its reputation, image, and credibility. It is a paramount precursor of consumer trust. In building trust, 
INTERNATIONAL JOURNAL OF ACADEMIC RESEARCH IN BUSINESS AND SOCIAL SCIENCES Vol. 10, No. 10, 2020, E-ISSN: 2222-6990 @ 2020 HRMARS

they also suggest that managers should devise CSR programmes that remind or reinforce perceptions of high service quality that leads to greater organizational recognition and association as well as greater purchase intent among consumers. There are three types of CSR activities: (i) moral/ethical (e.g. treating employees fairly and acting responsibly toward the environment), (ii) discretionary (e.g. contributing to arts and cultural programmes, contributing resources to raise social awareness of issues, and supporting children and family issues), and (iii) relational (e.g. striving to build long-term relations with its consumers and willing to listen to stakeholders). CSR perceptions are moderated by consumers' responses to the firm's type of CSR activity as well as the quality of its products (Sen and Bhattacharya, 2001). Awareness of an organization's CSR activities may help in times of crisis, as stakeholders are less likely to believe negative information about an organization given the positive perceptions built via its CSR programmes (Bhattacharya and Sen, 2004).

The findings of the study also reveal that the of notion corporate mission and value dissemination have an impact on the corporate image It addresses that the relationship between value and image in a corporate sector shows that is associated with problem solving process in an organisation. This relates to Melo (2012) stresses that corporate value is associated with the 'humanistic culture' in the organisation. Members in the organisation will involve, participate and collaborate in line with the organisation's goals and mission. The corporate values are focus on the organisation aims and visions of the company to achieve in the future which enhance the image but it is not a direct contributor to the company's earnings (Thomsen, 2005). Moreover, the formation of corporate image attractiveness perception is depending on the values judge by the stakeholders (Tran et al., 2015).

Meanwhile, image represents "the reasoned or emotional perceptions consumers attach to specific brands or services" (Low and Lamb, 2000). Corporate image enables an organisation to be readily distinguishable from competing brands in the marketplace. Distinguishing the brand from other brands can be in terms of associated brand attributes, benefits to users, and/or market segment emphasis, among other factors. This kind of explanation is observable through other researchers work such as Kazoleas, Kim and Moffitt (2001); Hatch, Schultz and Williamson (2003) and is coherent with the global vision of brands contributed by Keller (1993); Kaur and Soch (2013).

The expressive corporate value and its offerings as indicated by Yeo et al. (2011) are crucial and should be positively portrayed to prospects. The corporate brand building needs to be addressed by hotel services due to the current intense competition in the marketplace. The results obtained enable this study to confirm that corporate image is crucial to the hotels' performance. This strengthen the study of Kaur and Soch's (2013), they stressed on the notion of customer feeling about the service provider to their intention to be loyal or not is based on the corporate image.

The purpose of this research was to shed light on the vital mechanism at the edge and interface of marketing and CSR. We hope our study will inspire future research that further contributes to the understanding and consideration of a more vital role of CSR and CIA. Corporate Social Responsibility (CSR) is a concept whereby organizations serve the interests of society by taking responsibility for the impact of their activities on customers, employees, shareholders, communities and the environment in all aspects of their operations. These activities need to be seen as those that in the long-term would help secure a sustainable competitive advantage. Differential impacts of these components on 
perceived value, relationship quality (trust-credibility, trust-benevolence, affective commitment), and attitudinal loyalty.

This article has incorporated Bhattacharya et al. (2009)'s study and extended the customer driven corporate responsibility model suggested by Claydon (2011) in enhancing city hotels' corporate image and performance. Thus, it shows the model is a practical managerial tool for business managers to use and successfully incorporate CSR into their organization. CSR is extremely valuable in corporate identity building due to its ability to facilitate corporate image attractiveness, thus, increasing a firm's competitive advantage and overall performance. CSR and CIM activities must be tailored to the organizations' settings to ensure the organisation sustainability. CSR is extremely valuable in corporate identity building due to its ability to facilitate corporate image attractiveness as well as increasing a firm's competitive advantage and overall performance. Thus, it is an important factor in a decision-making process (Lin et al., 2020; Kim et al., 2016; Viruilaite \& Daubaraite, 2011) especially in the current level of complexity and competition in today's business environment. It also strengthened Martinez et al. (2014) that indicate marketers and the management of hotels need to enhance its CIA or Corporate image attractiveness through better CSR programs that will create positive perception among its customers. The programs will include the initiatives related to ethical and emotional aspects such as support the local community, environment, etc.

\section{Practical Implications}

These findings are also useful, as the management, especially within the service industry, should also take into account that CSR plans or initiatives can backfire if they are used as 'a tool solely to improve the brand equity rather than to improve relationships with main customers'. It is noted that such wrong emphasis may produce a boomerang or rebound effect whereby customers actually identified CSR initiatives as one of the main reasons for their dissatisfaction with the service company. Customers are often embedded within the company's social capital especially for small and medium size organisations.

Hence, CSR has proved to be equally vital for small and medium-sized and large companies not only as a means of cause-related marketing but as a way of producing and generating its niche and a competitive advantage in the market. In lean and slack times, marketers have to effectively make the most of limited resources. In order to survive the current prolonged period of slow economic growth, organizations must learn to do more with less. In the marketing field, this means making the most out of lower corporate marketing budgets. Thus, CSR approaches function well in corporate marketing budgets, therefore, managers can restructure their marketing spending without diminishing or withdrawing their corporate brand's existence for major customers because good reputation has an impact on the corporate success (Sagedar et al., 2018).

However, CEOs and managers must distinguish that the outcome of CSR investments is dependent on the industry and organizational setting they are facing. Results from this empirical study shows that the direct effect of CSR activities encourages significantly better outcomes in hospitality industry. This insinuates that CSR and Mission and CIM - Mission \& Value Dissemination activities must be tailored to the organizations' settings to ensure the success and effectiveness of their efforts to enhance their corporate image. The management should consider CSR as a vital means to amplify 
INTERNATIONAL JOURNAL OF ACADEMIC RESEARCH IN BUSINESS AND SOCIAL SCIENCES Vol. 10, No. 10, 2020, E-ISSN: 2222-6990 @ 2020 HRMARS

their image attractiveness, and, as such, are able to support and endorse image-building marketing activities that appeal to the target masses at large. Especially for service-based companies such as hotel, CSR emphasizes the identification of its niche customers with the company's high-quality services. As such, the respective marketing managers can therefore effectively facilitate and smooth the progress of CSR activities within the respective settings. Hence, hotels should continue to embed CSR within its core business model, which attracts more customers and makes them more profitable.

\section{Limitations and Directions for Future Research}

The present research should be assessed and evaluated carefully bearing in mind its limitations, which point to prospective avenues for future research. First, given the nature of influence method or mechanisms, other relevant variables should also be considered as boundary and limiting conditions of the correlation and their influence on CSR and marketing. Second, the research findings are limited by the comparatively small survey sample using convenience sampling, which may have resulted in sampling bias. Third, most of the survey respondents comprised 4-star hotels, which are not represented by general hotels such as motel, backpackers and home stay. A replication of this study is strongly recommended with larger sample sizes and greater representation from various groups of respondents (from all types and classes of hotel), where possible, utilizing probability and random sampling. Fourth, the research is also limited to certain customer's views of the organization. Hence, it may be useful to scrutinize the differences and similarities of CSR's impact and its effectiveness on the various groups of customers including investors and employees, and observe the explicit relations between CSR approaches and the respective stakeholder reactions as suggested by Bhattacharya et al. (2009). Future studies could investigate how CSR and its effects are perceived by the company itself compared to the view of external customers.

\section{References}

Achua, J. K. (2008). Corporate Social Responsibility in Nigerian Banking System. Society \& Business Review, 3(1), 57-71

AlChoiri, M. A. M., and Nurhadi, M. (2019) The Effect of Corporate Social Responsibility on Purchase Intention Through Brand Images as a Variable Mediation in Telkom Product in Surabaya, Journal of Business and Banking, 8 (2), 337.

Arendt, S., and Brettel, M. (2010). Understanding the Influence of Corporate Social Responsibility on Corporate Identity, Image and Firm Performance. Management Decision,48 (10), 1469-1492.

Ashworth, G., and Page, S. J. (2011) Urban Tourism Research Recent Progress and Current Paradoxes. Tourism Management, 32, 1 (February), 1-15.

Aurier, P., and Lanauze, G. S. (2011) Impacts of In-Store Manufacturer Brand Expression on Perceived Value, Relationship Quality and Attitudinal Loyalty, International Journal of Retail \& Distribution Management, 39,11, 810-835.

Aziz, N. A., \& Yasin, N. M. (2010) How Will Market Orientation and External Environment Influence the Performance Among SMEs in the Agro-Food Sector in Malaysia? International Business Research, 3, 3 (July).

Balmer, J. M. T. (1995) Corporate Branding and Connoisseurship. Journal of General Management, 21, $24-46$. 
INTERNATIONAL JOURNAL OF ACADEMIC RESEARCH IN BUSINESS AND SOCIAL SCIENCES

Vol. 10, No. 10, 2020, E-ISSN: 2222-6990 @ 2020 HRMARS

Bharadwaj, S. G., Menon, A. (1993) Determinants of Success in Service Industries. Journal of Services Marketing, 7, 19.

Bhattacharya, C. B., and Sen, S. (2003) Consumer-Company Identification: A Framework for Understanding Consumers' Relationships with Companies. Journal of Marketing, 67 (April), 76 88.

Bhattacharya, C. B., Korschun, D., and Sen, S. (2009), Strengthening Stakeholder Company Relationship Through Mutually Beneficial Corporate Social Responsibility Initiatives. Journal of Business Ethics, 85, 257-272.

Buil, J., Catalan, S., and Martinez, E. (2016) The Importance of Corporate Identity in Business Management. BRQ Business Research Quarterly, 19 (1), 3-12.

Brown, T., Dacin, P., Pratt, M., Whetten, D. (2006) Identity, Intended Image, Construed Image, and Reputation: An Interdisciplinary Framework and Suggested Terminology. Journal of the Academy of Marketing Science, 34, 99-106.

Clayton, J. (2011) A New Direction for CSR: The Shortcomings of Previous Models and The Rationale for A New Model. Social Responsibility Journal, 7 (September), 405-420.

Chan, T. J., and Saad. (2019) Predictors of Consumers' Purchase Intention Through Triple Bottom Line Corporate Social Responsible Practices: A study of the Branded Coffee Retailing Industry. Journal of Arts \& Social Sciences, 3 (1), 47-59.

Cornelius, N., Wallace, J., and Tassabehji, R. (2007) An Analysis of Corporate Social Responsibility, Corporate Identity and Ethics Teaching in Business Schools. Journal of Business Ethics, 76, 117 135.

Dowling, G. R. (1988). Measuring Corporate Images: A Review of Alternative Approaches. Journal of Business Research, 17, 27-34.

Ellen, P. S., Webb, D. J., and Mohr, L. A. (2006) Building Corporate Associations: Consumer Attributions for Corporate Socially Responsible Programs. Journal of the Academy of Marketing Science, 34(2), 147-157.

Fombrun, C. J. (1996) Reputation: Realizing Value from the Corporate Image. Harvard Business School Press, Boston, MA.

Frazier, P. A., and Barron, K. E., and Tix, A. P. (2004) Testing Moderator and Mediator Effects in Counseling Psychology Research. Journal of Counselling Psychology, 51 (1), 115-134.

Galbreath, J. (2010) How Does Corporate Social Responsibility Benefit Firms? Evidence from Australia. European Business Review, 22 (4), 411-431.

Gotsi, M., and Wilson, A. M. (2001) Corporate Reputation: Seeking A Definition. Corporate Communications: An International Journal, 6 (1), 24-30.

Haigh, M. M., and Brubaker, P. (2010) Examining How Image Restoration Strategy Impacts Perceptions of Corporate Social Responsibility, Organization-Public Relationships, and Source Credibility. Corporate Communications: An International Journal, 15 (4), $453-468$.

Hair, J. F., Anderson, R. E., Tatham, R. L., and Black, W. C. (1998) Multivariate Data Analysis with Readings, $4^{\text {th }}$ Edition, Prentice-Hall, Englewood Cliffs, NJ.

Hatch, M. J., Schultz, M., and Williamson, J. (2003) Bringing the Corporation into Corporate Branding. European Journal of Marketing, 37 (7/8), 1041-1064.

Huang, M-H., and Chang, Z-H. (2016) Strategies to Enhance Consumers' Identification with Service Firm. Journal of Services Marketing, 30 (4), 449-461. 
INTERNATIONAL JOURNAL OF ACADEMIC RESEARCH IN BUSINESS AND SOCIAL SCIENCES Vol. 10, No. 10, 2020, E-ISSN: 2222-6990 @ 2020 HRMARS

Jahdi, K., and Acikdilli, G. (2009) Marketing Communications and Corporate Social Responsibility (CSR): Marriage of Convenience or Shotgun Wedding? Journal of Business Ethics, 88, $103-113$.

Kaur, H., and Soch, H. (2013) Mediating Roles of Commitment and Corporate Image in the Formation Customer Loyalty. Journal of Indian Business Research, 5 (1),32-51

Kazoleas, D., Kim, Y., and Moffitt, M. A. (2001) Institutional Image: A Case Study. Corporate Communications: An International Journal, 6, 205-216.

Keller, K. L. (1993). Conceptualizing, Measuring and Managing Customer-Based Brand Equity. Journal of Marketing, 57(Jan), 1-22.

Kim, J., Song, H. J., and Lee, C-K. (2016) Effects of Corporate Social Responsibility and Internal Marketing on Organizational Commitment Turnover Intention. International Journal of Hospitality Management, 55, 25-32.

Knight, B., and Paterson, F. (2018) Behavioural Competencies of Sustainability Leaders: An Empirical Investigation. Journal of Organizational Change Management, 31(3), 557-580.

Kotler, P., and Lee, N. (2005) Corporate Social Responsibility, Hoboken, NK: John Wiley \& Sons Inc.

Lichenstein, D. R., Drumwright, M. E., and Braig, B. (2004) The Effect of Corporate Social Responsibility on Customer Donations to Corporate-Supported Non- Profits. Journal of Marketing, 68(4), 1632.

Lim, W. L., Ho, J. A., Lee, C., and Ng, S. I. (2020) Impact of Positive and Negative Corporate Social Responsibility on Automotive Firms' Financial Performance. A Market Based Asset Perspective. Corporate Social Responsibility and Environment Management, 27(4) July/August, 1761-1773.

Low, G. S., and Lamb, C. W. (2000) The Measurement and Dimensionality of Brand Associations. Journal of Product \& Brand Management, 9(6), 350-68.

Inoue, Y., and Lee, S. (2011) Effects of Different Dimensions of corporate social responsibility on corporate financial performance in tourism related industries, Tourism Management, Vol. 32, pp.790-804.

Maignan, I., and Ralston, D. A. (2002) Corporate Social Responsibility in Europe and the US: Insights from Businesses' Self-Presentations. Journal of International Business Studies, 33, 497-514.

Martinez, P., Perez, A., and Rodriques-del Bosque, A. (2014) CSR Influence on Hotel Brand Image and Loyalty. Academia Revista Latinoamericana de Administracion, 7 (2), 267-283.

McWilliams, A., and Siegel, D. (2001) Corporate Social Responsibility: A Theory of the Firm Perspective. Academy of Management Review, 26, 117 - 127.

Melewar, T. C., Sarstedt, M., and Hallier, C. (2012) Corporate Identity, Image and Reputation Management: A Further Analysis. Corporate Communications: An International Journal, 17(1) http:doi.org/10.1108/ccij.2012.16817aaa.002

Melo, T. (2012) Determinants of Corporate Social Performance: The Influence of Organisational Culture, Management Tenure and Financial Performance. Social Responsibility Journal, 8(1), 3347.

Moir, L. (2001) What Do We Mean by Corporate Social Responsibility. Corporate Governance, 1 (2), $16-22$.

Kakabadse, N. K., Kakabadse, A., and Lee Davies. L. (2009) CSR Leaders Road Map. Corporate Governance, 9 (1), 50 - 57.

Nunnaly, J. O. (1978) Psychometric Theory, New York: McGraw-Hill.

Ogba, I-E., \& Tan, Z. (2009) Exploring the Impact of Brand Image on Customer Loyalty and Commitment in China. Journal of Technology Management in China, 4(2), $132-144$. 
INTERNATIONAL JOURNAL OF ACADEMIC RESEARCH IN BUSINESS AND SOCIAL SCIENCES

Vol. 10, No. 10, 2020, E-ISSN: 2222-6990 @ 2020 HRMARS

Polonsky, M. J., and Oslen, G. D. (2004) The Role of Brand/Cause Fit in the Effectiveness of Cause Related Marketing:Complementarities and Conflicts. European Journal of Marketing, 35, 13611385.

Potluri, R. M., Batima, Y., and Madiyar, K. (2010) Corporate Social Responsibility: A Study of Kazakhstan Corporate Sector. Social Responsibility Journal, 6 (1), 33 - 44.

Sageder, M., Mitter, C., and Feldbauer-Durstmuller, B. (2018) Image and Reputation of Family Firms. A systematic Literature Review of the State of Research. Review of Managerial Science, 12(1), 335-377.

Said, R., Zainuddin, Y., and Haron, H. (2009) The Relationship Between Corporate Social Responsibility Disclosure and Corporate Governance Characteristics in Malaysian Public Listed Companies. Social Responsibility Journal, 5(2), 212 - 216.

Sen, S., and Bhattacharya, C. B. (2001) Does doing good always lead to doing better? Consumer Reactions to Corporate Social Responsibility. Journal of Marketing Research, 38, 225 - 243.

Sheikh, S., and Beise-Zee, R. (2011) Corporate Social Responsibility or Cause-Related Marketing? The Role of Cause Specificity of CSR. Journal of Consumer Marketing, 28 (1), $27-39$.

Simoes, C., and Dibb, S. (2008) Illustrations of the Internal Management of Corporate Identity in Melewar, T.C.(Ed.), Facets of Corporate Identity, Communication and Reputation, Routlege, New York, NY.

Snider, J., Hill, R. P., and Martin, D. (2003) Corporate Social Responsibility in the $21^{\text {st }}$ Century: A View from the World's Most Successful Firms. Journal of Business Ethics, 48, 175 - 187.

Thomas, J. G. (2000) Macro-environmental forces in Helms, M.M (Ed.), Encyclopedia of Management, $4^{\text {th }}$ ed., Gale Group, Farmington Hills, MI, $516-520$.

Thomsen, T. (2005) Corporate Governance as a Determinant of Corporate Values. Corporate Governance: The International Journal of Business in Society, 5(4), 10-27.

Tong, C., and Wong. A. (2016).The Effect of Corporate Social Responsibility of Fast -Food Restaurants on Corporate Reputation. Journal of Marketing \& HR, 3(1), 126-141

Tran, M. A., Nguyen, B., Melewar, T. C., and Bodoh, J. (2015) Exploring the corporate image formation process. Qualitative Market Research: An International Journal, 18 (1), 86-114.

Van Riel, C. B. M. (1995) Principles of Corporate Communication, Prentice-Hall, London.

Varadarajan, P. R., and Menon, A. (1988) Cause-Related Marketing: A Co Alignment of Marketing Strategy and Corporate Philanthropy. Journal of Marketing, 52, 58-74.

Viruilaite, R., and Daubaraite, U. (2011) Corporate social responsibility in forming corporate image. Inzinerine Ekonomika- Engineering Economics, 22(5), 534-543

Vlachos, P. A., Tsamakos, A., Vrechopoulus, A. P., and Avramidids, P. K. (2009) Corporate Social Responsibility: Attributions, Loyalty, and the Mediating Role of Trust. Journal of the Academy of Marketing Science, 37 (2), $170-180$.

Weber, M. (2008) The Business Case for Corporate Social Responsibility: A Company Level Measurement Approach for CSR. European Management Journal, 26 (4), 247-261.

Williamson, D., Wood, G. L., and Ransay, J. (2005). Drivers of Environmental Behaviour in Manufacturing SMEs \& the Implications for CSR. Journal of Business Ethics, 67 (3), 317-330.

Wood, D. J. (1991) Corporate Social Performance Revisited. Academy of Management Review, 16 (4), 691-718.

Worcester, R. (2009) Reflections on Corporate Reputations. Management Decision, 47, 573-589. 
INTERNATIONAL JOURNAL OF ACADEMIC RESEARCH IN BUSINESS AND SOCIAL SCIENCES Vol. 10, No. 10, 2020, E-ISSN: 2222-6990 @ 2020 HRMARS

Yeo, R. K., Goh, M., and Tso, S. (2011) Corporate Image and Reputation of Large Mainland Chinese Enterprises. Journal of Marketing Communications, 17 (3), 195-211.

Zairi, M., and Peters, J. (2002) The Impact of Social Responsibility on Business Performance. Managerial Auditing Journal, 17, 174-184 